\title{
The effectiveness of filters on catfish Clarias gariepinus fry performance in the aquaponic system
}

\section{Efektivitas filter terhadap performa benih ikan lele Clarias gariepinus pada sistem akuaponik}

\author{
Yuli Andriani ${ }^{*}$, Zahidah Hasan ${ }^{1}$, Irfan Zidni ${ }^{1}$, Isni Nurruhwati ${ }^{1}$, Iskandar ${ }^{1}$, \\ Rahmadi Kusumoputra ${ }^{1}$ \\ ${ }^{1}$ Department of Fisheries, Faculty of Fisheries and Marine Sciences, University of Padjadjaran, \\ Bandung, West Java, Indonesia \\ *Corresponding author: yuli.andriani@unpad.ac.id
}

(Received April 29, 2019; Accepted May 12, 2019)

\begin{abstract}
This study aimed to determine the effectiveness of filters on the growth performances of catfish fry (Clarias gariepinus) in the aquaponic system. The study was conducted in the Ciparanje Green House, Faculty of Fisheries and Marine Sciences, University of Padjadjaran, Jatinangor. A completely randomized design with four treatments and three replications was applied, namely treatment A: Water circulation using bioball filter medium, B: Water circulation using water spinach filter medium, C: Water circulation using bioball and water spinach filter media, and D: Water circulation using sponge filter medium (control). The container used for the maintenance was a fiber tank at $70 \mathrm{~cm} \times 70 \mathrm{~cm} \times 70 \mathrm{~cm}$ size filled with $257 \mathrm{~L}$ water and a stocking density of 15 fish/fiber. The parameters observed were survival rate, growth, feed conversion, and water quality. The results showed that the use of biological filter using water spinach produced the best growth performance of catfish. The best survival rate was also obtained by using water spinach filter (100\%) with the absolute growth of $98.32 \pm 15.6 \mathrm{~g}$. The water quality an aquaponic system with water spinach filter supported the growth performance of catfish fry.
\end{abstract}

Keywords: absolute growth, aquaponic, Clarias gariepinus, filters.

\begin{abstract}
ABSTRAK
Penelitian ini bertujuan menguji efektivitas filter terhadap performa pertumbuhan benih ikan lele Clarias gariepinus dalam sistem akuaponik. Penelitian dilakukan di Laboratorium Rumah Kaca Ciparanje, Fakultas Perikanan dan Ilmu Kelautan, Universitas Padjadjaran, Jatinangor. Metode penelitian adalah rancangan acak lengkap dengan empat perlakuan dan tiga ulangan, yaitu perlakuan A: sirkulasi menggunakan media filter bioball, B: Sirkulasi menggunakan media filter bayam air, C: Sirkulasi menggunakan media filter bioball dan tanaman kangkung, dan D : Sirkulasi menggunakan media spons (kontrol). Wadah yang digunakan untuk pemeliharaan bak fiber dengan ukuran $70 \mathrm{~cm} \times 70 \mathrm{~cm} \times 70 \mathrm{~cm}$ diisi dengan air sebanyak $257 \mathrm{~L}$ dengan padat tebar 15 ekor / bak. Parameter yang diamati adalah kelangsungan hidup, pertumbuhan ikan, konversi pakan dan kualitas air. Hasil penelitian menunjukkan bahwa penggunaan filter biologis menggunakan tanaman kangkung menghasilkan performa pertumbuhan ikan lele yang terbaik. Tingkat kelangsungan hidup terbaik juga ditunjukkan oleh pelakuran dengan filter berupa tanaman kankung (100\%) dan pertumbuhan mutlak 98,32 \pm 15,6 g. Kualitas air sistem akuaponik dengan filter tanaman kangkung mendukung performa pertumbuhan benih ikan lele.
\end{abstract}

Kata kunci: akuaponik, Clarias gariepinus, filter, pertumbuhan mutlak. 


\section{INTRODUCTION}

Catfish is a consumed fish favored by the Indonesian community. High consumer demand on catfish is due to savory taste, thick meat, and cheaper price than other freshwater fish. This condition urges the catfish culture in Indonesia is more developed as the time goes. In 20102013, the catfish production showed a very good production as increased by $47.21 \%$. Based on this production value, Indonesia became the first rank of catfish producing country in 2011 (Directorate General of Aquaculture, 2013). A technology that can be used to culture catfish is by using the aquaponic system.

Aquaponic is a combination of aquaculture and hydroponic with the goal to maintain fish and plant in an integrated system (Yep \& Zheng, 2019). Interaction between fish and plant produces an ideal environment for growing, resulting in a more productive condition than conventional method (Zidni et al., 2013; Turnsek et al., 2020). The aquaponic system reduces the organic substances by absorbing the culture water waste with plants (Yang \& Kim, 2019; Dauhan \& Suparmono, 2014). Plants are grown in a hydroponic system with the roots submerged in water (Johnson et al., 2017). Plants in this condition are functioned as biofilters that can decompose toxic substances into non-dangerous substances for fish, followed by supplying the oxygen to the water used for fish maintenance (Zidni et al., 2019b).

Aquaponic is developing due to less land and water availability for fish culture, which can use water efficiently as culture medium. On the other hand, a good water quality is an important factor in fish and shrimp culture, including catfish, which can increase the fish culture productivity (Gichana, 2019; Pinheiro et al 2020). An effort that can be done to maintain the water quality in aquaponic system is by using a filter (Danner, 2019; Lennard, 2012; Darmayanti et al., 2011). The filter used can be plants, bioballs, gravel, coconut husks, sponges, or a combination of two or more filter types (Samsundari \& Wirawan, 2013; Kushayadi, 2018; Alam, 2019).

Water spinach is one of the plants often used in an aquaponic system (Dauhan \& Suparmono, 2014). Andriani (2019) mentioned that water spinach is a fast-growing plant that produces the best water quality aquaponic system with long and fibrous roots. Based on this condition, a further study is required to determine the filter effectiveness on catfish (Clarias gariepinus) fry culture in aquaponic system.

\section{MATERIALS AND METHODS}

\section{Equipments and materials}

The catfish fries used in this study had 5-8 cm size and were stocked at $15 \mathrm{fries} / \mathrm{m}^{2}$. The study used water spinaches on 1-2 weeks old obtained from the seeding result with rockwools as plantgrowing media. Rockwool serves as a plant root place to attach and stick the plant firmly in the pot. The feed applied was a commercial pellet feed with $35 \%$ protein content.

\section{Study Design}

This study applied an experimental method using a completely randomized design (Gazpersz, 1991). The treatments were different filter types on a water circulation, namely: (A) water circulation with bioball filter medium, (B) water circulation with water spinach filter medium, (C) water circulation with bioball and water spinach media, and (D) water circulation with sponge medium (control). Each treatment was applied in three replications.

\section{Container preparation}

Recirculation system

A recirculation system was set at Ciparanje Green House, Faculty of Fisheries and Marine Sciences, Universitas Padjajaran, Jatinangor, West Java. The recirculation system design used is presented in Figure 1. The containers used in this study were 12 fiber tanks with $70 \mathrm{~cm} \times 70 \mathrm{~cm} \times 70$ $\mathrm{cm}$ size. The fiber tank was organized randomly based on the treatments applied and placed on a shelf in the green house. The tank was filled with $275 \mathrm{~L}$ water.

The pump was used to pull the water out of the fish maintenance tank to the 4" PVC pipe as plants place. The 12 pumps were required (one pump for each tank) with 90 -watt (4 meter) and 25 -watt ( 2 meter) size. The 12 heaters were used to stabilize the water temperature. The 4" PVC and $1 / 2$ " PVC were utilized as a container to flow or hold the water for the plants. Four mechanic filters were used to filter the water in the control fiber tank that contained foam, dacron, fibers, and filter-mate. The 76 plastic glasses were used as plant places. The biological filter (bioball) was used at 120 pieces. An iron shelf at $3 \mathrm{~m} \times 1 \mathrm{~m} \times 2$ $\mathrm{m}$ was used to place the pipe. 


\section{Filter media container preparation}

The filter media container in this study was made from 12 units of 4-inch PVC pipe. The PVC pipe was initially perforated at $6.5 \mathrm{~cm}$ diameter. The water pump and water-flow were installed in the tank and directed to the water holding pipe (Figure 1). The recirculation system was allowed to run for a week to stabilize the dissolved oxygen (DO) and $\mathrm{pH}$ levels. In addition, water stabilization was also carried out to proliferate the nitrifying bacteria.

\section{Fish fry and plant sortation}

The catfish fries used were obtained from the fish farmer in Bandung. The catfish fries used were at $5-8 \mathrm{~cm}$ size and stocked at $15 \mathrm{fries} / \mathrm{m}^{2}$. Before stocking, 30 fries were taken for initial length and growth measurement sampling. Stocking was performed at 3 days after the recirculation system was stable.

The vegetables used were water spinaches on 1-2 weeks old obtained from the seeding result with rockwools as plant-growing media. Rockwool serves as plant root place to attach and stick the plant firmly in the pot.

\section{Plant seeding}

The plant seeding process was performed by planting the water spinach seeds in a net pot filled with soil and rockwool. The water spinach seeds were sown into rockwool drabbled with water. After the water spinach roots were visibly elongated, the plants were then sorted. The sorted plants were moved into the plastic glasses plant containers placed in the pipe holes.

\section{Fish maintenance}

Fish were maintained at $1 \mathrm{fish} / 2 \mathrm{~L}$ water stocking. The study was performed for 30 days. Fish were fed with a commercial feed at $35 \%$ protein content. The amount of feed fed was $3 \%$ of the biomass with twice a day frequency, namely 09.00 and $15.00($ GMT +7). Measurement was performed on the initial study period (Wo), then the weight sampling was performed every week. The number of dead fish was noted everyday.

\section{Parameters}

Survival rate

Survival rate was calculated using the following formula (Effendie 1979):

$$
\mathrm{SR}=\frac{\mathrm{N}_{\mathrm{t}}}{\mathrm{N}_{0}} \times 100
$$

Note:

SR = Fish survival rate $(\%)$

$\mathrm{Nt}=$ The number of fish in the final study period (fish)

No $=$ The number of fish in the initial study period (fish)

\section{Absolute growth}

Weight growth measurement was performed by measuring the weight of 30 fish samples. Weight was measured using a digital scale (Panasonic Kenko Electric, Co. Ltd., Japan) with $0.1 \mathrm{~g}$ accuracy. The absolute growth was calculated by using the following formula (Ogunji et al., 2008):

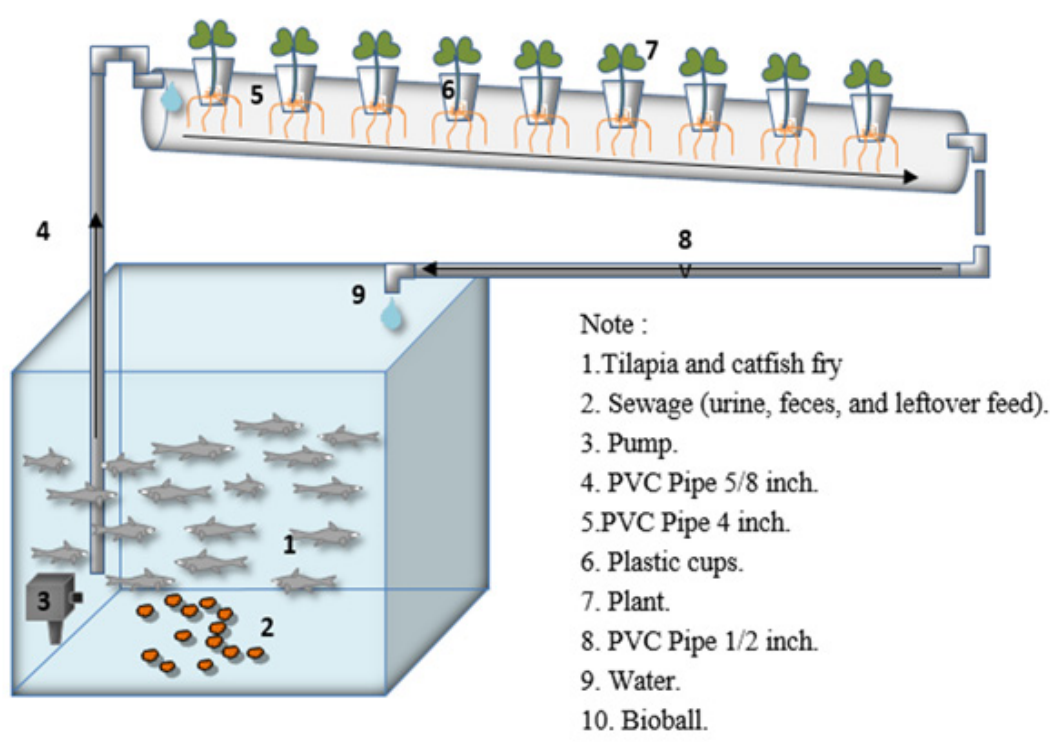

Figure 1. Recirculation system installation scheme 
Note:

$$
\mathrm{AG}=\mathrm{W}_{\mathrm{t}}-\mathrm{W}_{\mathrm{o}}
$$

$\mathrm{AG} \quad=$ Absolute growth $(\mathrm{g})$

$\mathrm{W}_{\mathrm{t}} \quad=$ Final fish weight $(\mathrm{g})$

$\mathrm{W}_{0} \quad=$ Initial fish weight $(\mathrm{g})$

Specific growth rate (SGR)

The specific growth rate (SGR) was calculated by using Effendie (1997) in the following formula:

$$
\operatorname{SGR}(\% / \text { day })=\left[\sqrt[t]{\frac{\mathrm{Wt}}{\mathrm{Wo}}}-1\right] \times 100
$$

Note:

SGR = Specific growth rate $(\% /$ day $)$

Wo $\quad=$ Initial fish weight $(\mathrm{g})$

$\mathrm{Wt} \quad=$ Final fish weight $(\mathrm{g})$

$\mathrm{T}=$ Maintenance period (day)

\section{Feed conversion ratio}

Feed conversion ratio (FCR) was measured at the final observation period and calculated based on Djarijah (1995):

$$
\mathrm{FCR}=\frac{\text { Feed consumed by fish }}{\mathrm{Wt}+\mathrm{Wd}-\mathrm{Wo}}
$$

Note :

\begin{tabular}{|c|c|c|c|c|c|}
\hline No. & Parameter & Analysis method & Equipment & Location & Measurement period \\
\hline 1 & $\begin{array}{c}\text { Dissolved } \\
\text { oxygen (DO) }\end{array}$ & Potentiometer & DO meter & In-situ & Once in 7 days \\
\hline 2 & Ammonia & Spectrophotometry & Spectrophotometer & $L a b$ & $\begin{array}{l}\text { Initial, during, and } \\
\text { final maintenance } \\
\text { period }\end{array}$ \\
\hline 3 & Nitrate & Spectrophotometry & Spectrophotometer & $L a b$ & $\begin{array}{l}\text { Initial, during, and } \\
\text { final maintenance } \\
\text { period }\end{array}$ \\
\hline 4. & Phosphate & Spectrophotometry & Spectrophotometer & $L a b$ & $\begin{array}{l}\text { Initial, during, and } \\
\text { final maintenance } \\
\text { period }\end{array}$ \\
\hline 5 & $\mathrm{pH}$ & Potentiometer & $\mathrm{pH}$ meter & In-situ & Once in 7 days \\
\hline 6 & Temperature & Potentiometer & Thermometer & In-situ & Everyday \\
\hline
\end{tabular}

$$
\begin{aligned}
\mathrm{F}= & \text { Feed weight fed during the maintenance } \\
& \text { period }(\mathrm{g}) \\
\mathrm{Wt}= & \text { Fish biomass weight at the final } \\
& \text { maintenance period }(\mathrm{g}) \\
\mathrm{Wo}= & \begin{array}{l}
\text { Fish biomass weight at the initial } \\
\\
\text { maintenance period }(\mathrm{g})
\end{array} \\
\mathrm{Wd}= & \begin{array}{l}
\text { Dead fish weight during maintenance } \\
\text { period }(\mathrm{g})
\end{array}
\end{aligned}
$$

Table 1. Water quality measurement method

\section{Water quality}

The inlet canal to the maintenance tank carried a water supply from the biological filter, meanwhile the outlet canal from the maintenance tank carried feed remains and excretion product containing ammonia and carbon dioxide. To avoid blockage in the outlet, the outlet was cleaned and syphoned everyday, then the water was added at $10 \%$.

The water quality parameters, namely temperature was measured everyday, DO and $\mathrm{pH}$ were measured once in 7 days, ammonia, nitrite, and phosphate were measured on the initial, during, and final maintenance period. The measured/analyzed parameters along with the measurement method and equipments used were presented in Table 1.

\section{Data analysis}

Data were analyzed using the analysis of variance (F-test). When the analysis of variance showed a significant different result, then the analysis was continued with the Duncan test at 95\% degree of confidence level to compare the value obtained among the treatments (Gasperz, 1991).

\section{RESULTS AND DISCUSSIONS}

\section{Results \\ Survival rate}

The survival rate of catfish fry maintained for 30 days in the aquaponic culture system is presented in Figure 2. The highest survival rate of catfish fry was obtained from the B (plant) treatment at $100 \%$, which was insignificantly different from the $\mathrm{C}$ (bioball and plant: $86.67 \%$ )

(n)


and A (bioball: $80 \%$ ) treatments, but higher $(\mathrm{P}<0.05)$ than the $\mathrm{D}$ treatment $(40 \%)$.

\section{Absolute growth}

The absolute growth of catfish fry increased in all treatments shows in Figure 3. The absolute growth of catfish fry in the A (86.64), B (98.32 g), and $\mathrm{C}(74.53 \mathrm{~g})$ treatments were higher $(\mathrm{P}<0.05)$ than the D treatment $(13.66 \mathrm{~g})$.

\section{Specific growth rate}

The specific growth rate of catfish fry maintained in an aquaponic system with different filter treatments is presented in Figure 4. The observation result showed that the specific growth rate of catfish fry in the B (4.03\%/day), A (3.72 $\% /$ day) and $\mathrm{C}$ (3.56\%/day) treatments ase similar $(\mathrm{P}>0.05)$, but higher than the $\mathrm{D}$ treatment $(2.27$ $\% /$ day).

\section{Feed conversion}

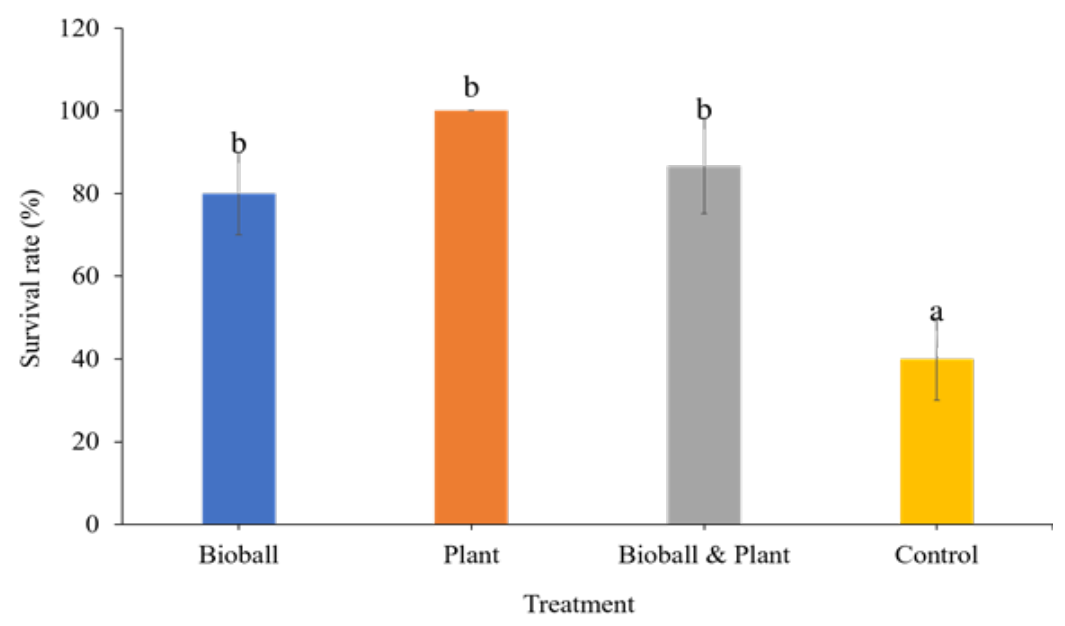

Figure 2. The survival rate of catfish fry. Note: Numbers followed by the same letter show an insignificant difference $(\mathrm{P}>0.05)$

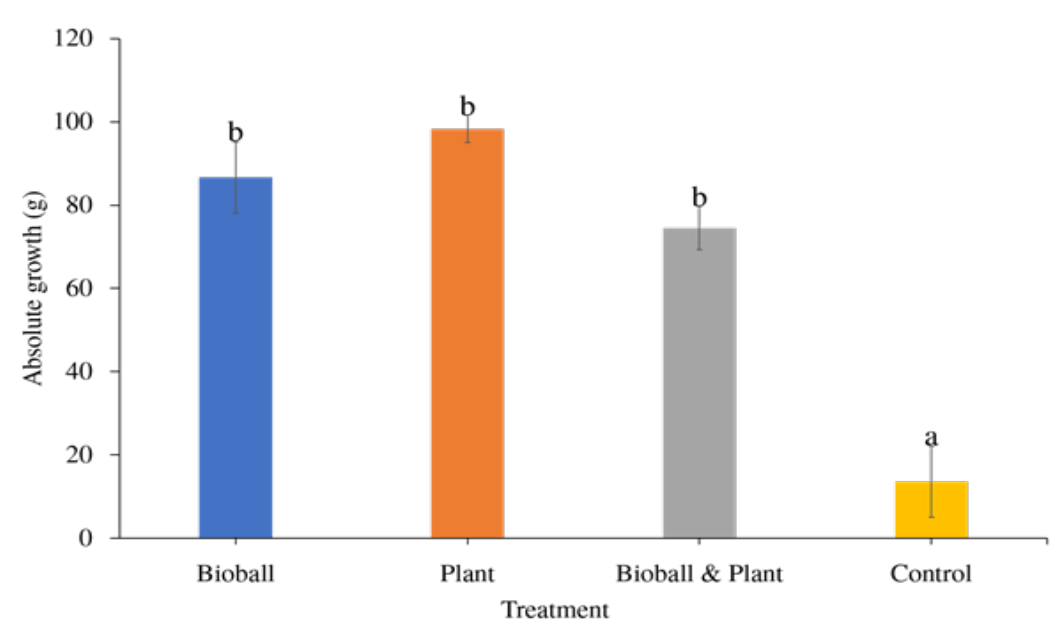

Figure 3. Absolute growth of catfish fry maintained in an aquaponic system with different filter treatments. Note: Numbers followed by the same letter show an insignificant difference $(\mathrm{P}>0.05)$
Feed conversion ratio (FCR) is the amount of feed required by fish to produce $1 \mathrm{~kg}$ biomass (Andriani et al., 2018). The study result showed that the FCR value was similar in all treatments (Figure 5).

\section{Water quality}

The water quality data are presented in Figure 6-11. The measurement result of dissolved oxygen during the maintenance period was fluctuating between 5.2-7.7 $\mathrm{mg} / \mathrm{L}$ (Figure 6). The $\mathrm{pH}$ value was betweeng 7.47-8.57. Each treatment occurred a declined $\mathrm{pH}$ value on the second week (Figure 7). The water temperature during the maintenance period was fluctuating between $20.10-21.87^{\circ} \mathrm{C}$ (Figure 8). The recommended optimal environmental temperature for catfish is $23-30^{\circ} \mathrm{C}$ (SNI 2000). The ammonia concentration during the maintenance period was fluctuating betweong $0.0025-0.125 \mathrm{mg} / \mathrm{L}$ (Figure 9). The

\section{$(\mathrm{P}>0.05)$}

. 
water nitrate content was between $0.20-0.34$ $\mathrm{mg} / \mathrm{L}$ (Figure 10). The water phosphate content during the catfish maintenance period was also fluctuating betweong 0.22-1.58 mg/L (Figure 11). On the second week, the phosphate concentration declined in the B (plant) and C (bioball and plant) treatments.

\section{Discussions}

The use of various filters in an aquaponic system in this study influenced the performance of survival rate, growth, and feed conversion of catfish. Filters are important component to maintain the water quality due to limited water use in aquaponic system (Siswadi \& Yuwono, 2019; Alfia et al., 2013). The results showed that

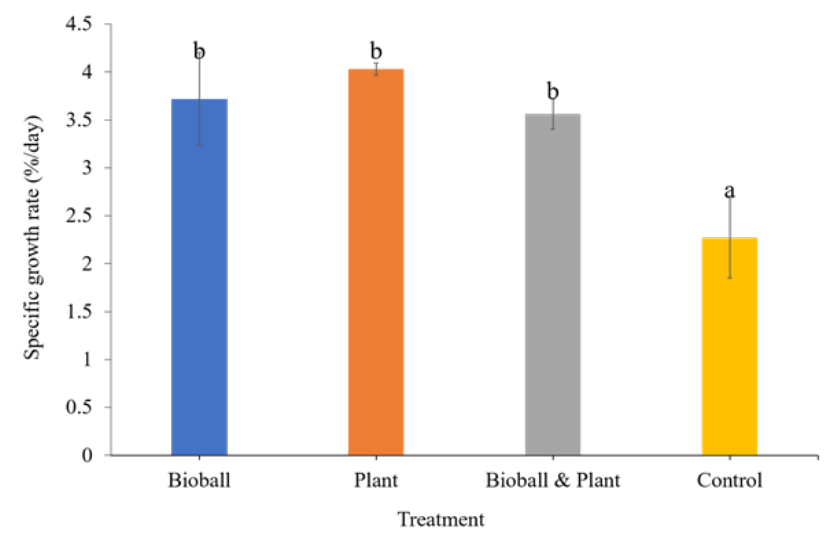

Figure 4. Specific growth rate of catfish fry. Note: Numbers followed by the same letter show an insignificant difference $(\mathrm{P}>0.05)$.

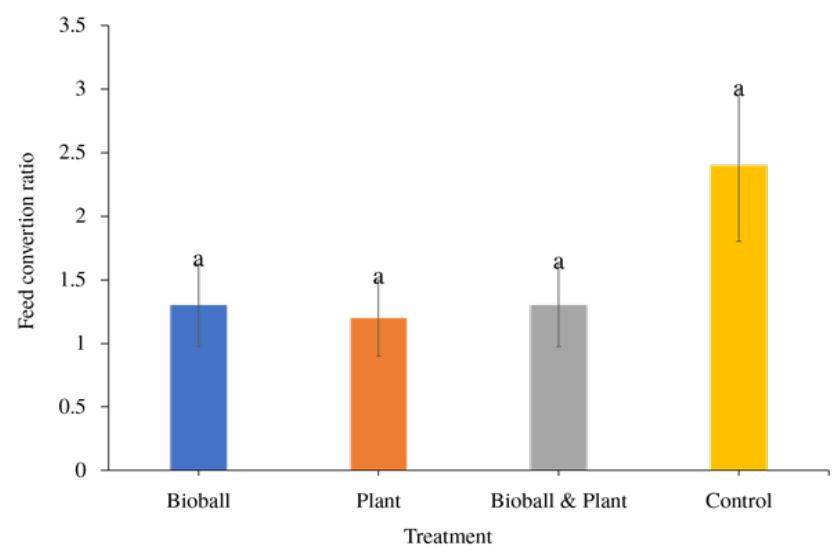

Figure 5. Feed conversion of catfish fry maintained in an aquaponic system with different filter treatments. Note: Numbers followed by the same letter show an insignificant difference $(\mathrm{P}>0.05)$.

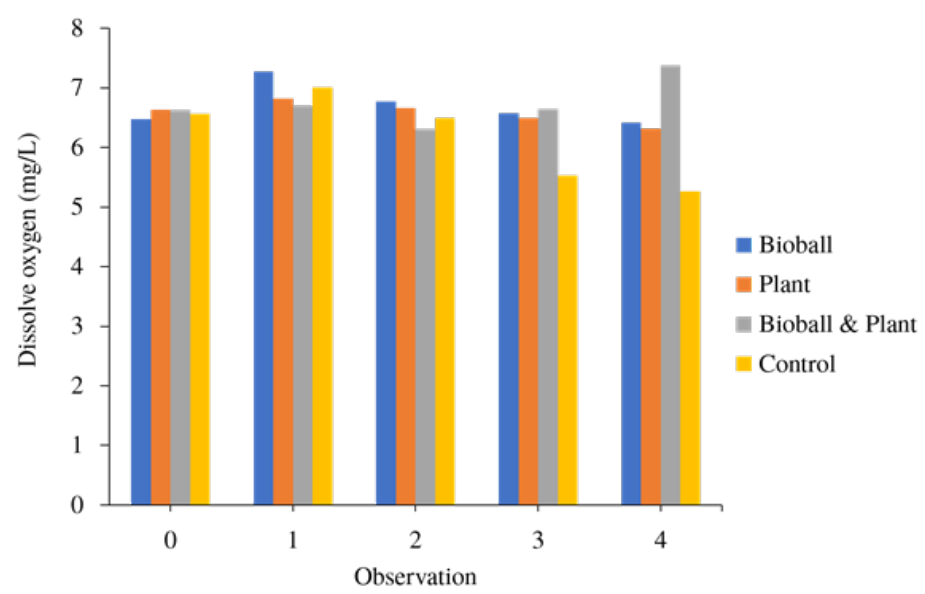

Figure 6. Dissolved oxygen content in an aquaponic system with different filter treatments. 
catfish cultured with plant filters in the treatment B obtained the highest survival rate and growth compared to all treatments. The survival rate in the treatment $\mathrm{B}$ reached $100 \%$ and the growth rate was $4.03 \% / d a y$, while the feed conversion value in the $\mathrm{B}$ treatment was 1.2 , as insignificantly different from other treatments $(\mathrm{P}>0.05)$.

The fish survival rate and growth are influenced by the internal (type, size, and genetics) and external factors, i.e water quality (Mahavadiya et $a l ., 2018)$. The use of water spinach as a biofilter was positively correlated to the catfish survival rate of catfish in this study. Biological filters have several advantages compared to physical filters, which can convert toxic metabolic waste from the fish feed into non-toxic substance such as converting ammonia to nitrite and nitrate (Effendi et al., 2016; Stathopoulou et al., 2018).

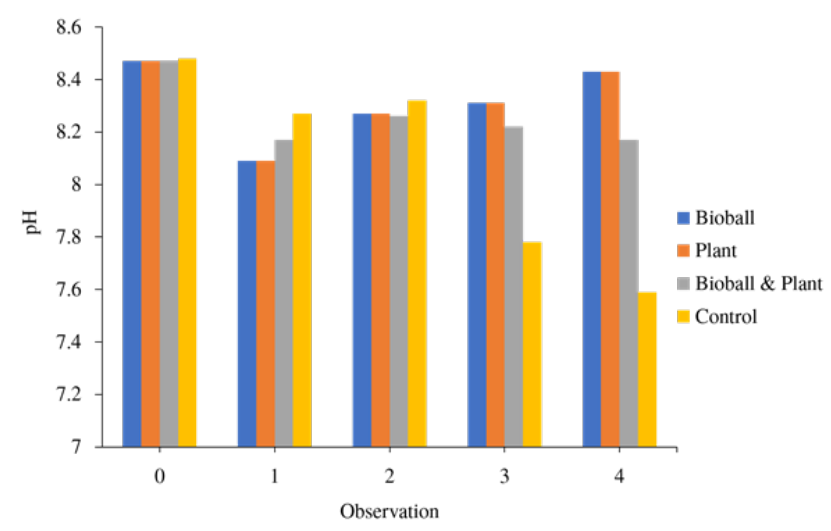

Figure 7. The $\mathrm{pH}$ value in aquaponic system with different filter treatments.

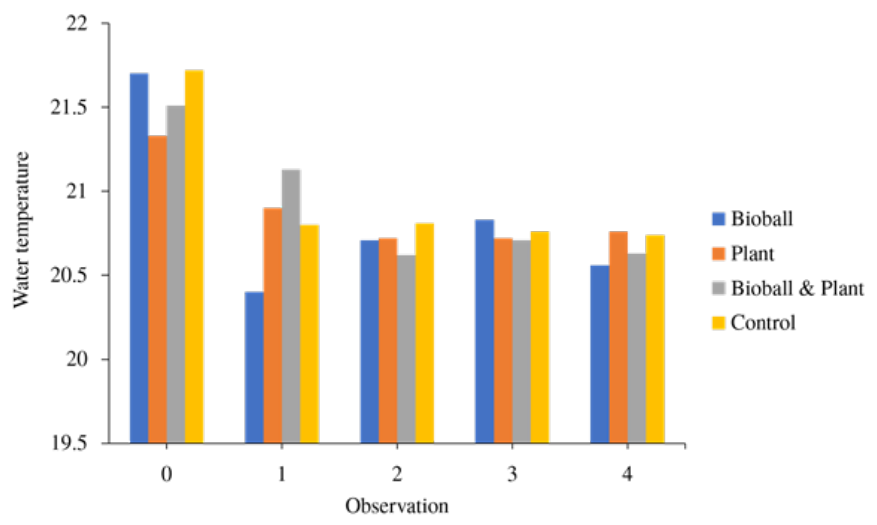

Figure 8. Water temperature in aquaponic system with different filter treatments.

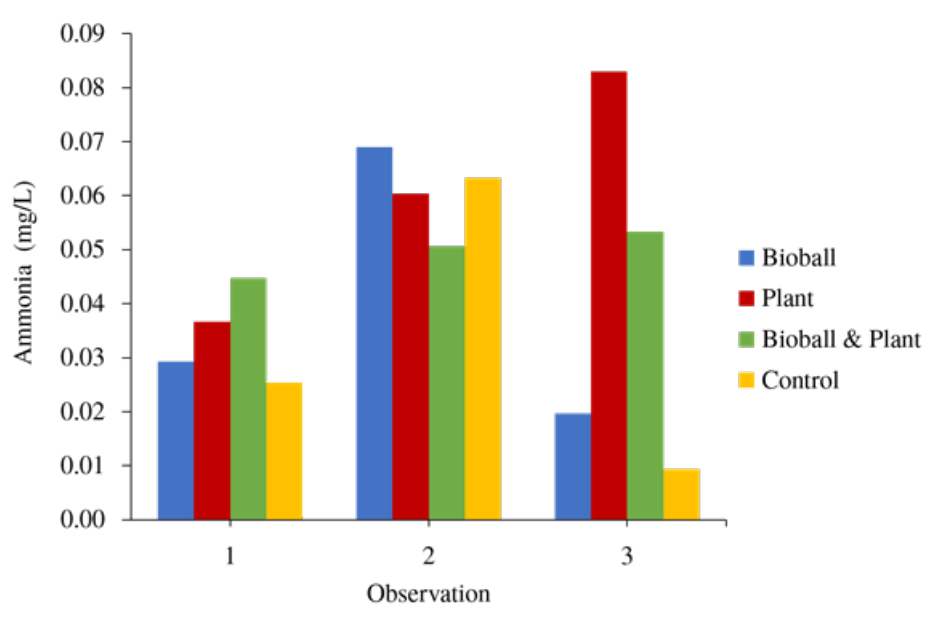

Figure 9. Ammonia content in aquaponic system with different filter treatments. 
This biological decomposition mechanism is also assisted by several bacteria (Nitrosomonas spp., Nitrobacter spp., etc.) that can grow in the biological filter media (Patillo, 2017; Fauzzia et al., 2013).

The highest survival rate of catfish fry in the B treatment $(100 \%)$ showed a better value than Wicaksana et al. (2015), who used a combination of various filter types in aquaponic system. The study results of Wicaksana et al. (2015) reported that the survival rate of catfish fry in an aquaponic biofilter system using water spinach filter obtained the highest value $92.17 \%$. High survival rate in this study was thought to be associated with a normal stocking density (1 fry/2 L). Boxman et al. (2018) stated that fish stocking density and plant species are the determining factors in aquaponic culture productivity. For example, a marine aquaponic system with high stocking density produced a lower survival rate $(79 \%)$. Overall, the survival rate of catfish fry in this study was still quite high as still above $80 \%$ (SNI, 2000).

The catfish growth in aquaponic system is also influenced by the filter used. The results showed that the biological filter, such as plants and bioball, or a combination of both filters, produced better catfish growth than the physical filter in the control treatment. This condition indicates that the biological filter has more advantage than the physical filter.

This condition followed the study results of Kamauddin et al. (2019) who stated that the use of cocopeat as a physical filter was insufficient to be utilized for water treatment in aquaponic system. The capability of water spinach as a good biological filter for catfish in aquaponic system was strengthened by the study results of Zahidah et al. (2018) and Nazlia and Zulfiadi (2018). Zahidah et al. (2018) stated that the combination of catfish and water spinach in an aquaponic system produced the best absolute growth rate at $7.8 \pm 1.18 \mathrm{~g}$. Meanwhile, the study results of Nazlia and Zulfiadi (2018) showed the highest survival rate and absolute growth rate of catfish in aquaponic system were obtained from the water spinach treatment, namely at $86.7 \%$ and $1.97 \mathrm{~g}$, respectively. According to Setijaningsih and Suryaningrum (2015), water spinach is more

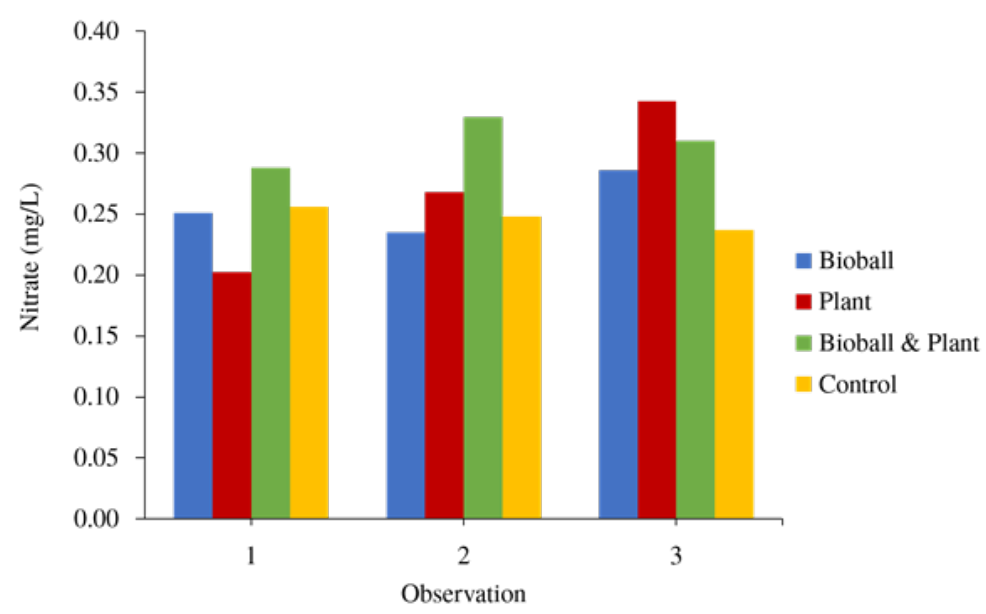

Figure 10. Nitrate content in aquaponic system with different filter treatments.

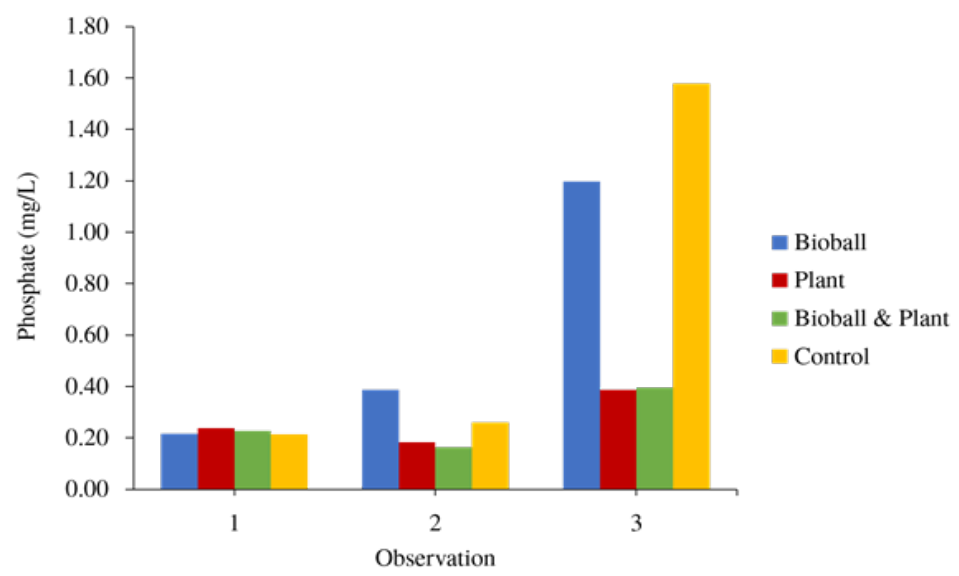

Figure 11. Phosphate content in aquaponic system with different filter treatments. 
effective to utilize nutrients in the flowing water from the catfish maintenance tank. Moreover, the use of fine bubbles in aquaponic system combined with water spinach produced higher striped catfish growth than the conventional aquaponic system, namely at $6.68 \pm 0.43$ (Naomi et al., 2020).

Catfish tends to have a high growth rate compared to other fish. This is related to the food habit of catfish which is omnivorous and can accept various feed types. The highest average specific growth rate of catfish fry in this study (4.03\%/day) was not much different from the study results of Wicaksana (2015), who reported the average specific growth rate value of African catfish fry was $4.21 \%$ /day in an aquaponic system with water spinach filter. Ekasari et al. (2019); Sulli et al. (2018) stated that growth and health status of several aquaculture species are varied depending on the species and feed source.

In contrast with the survival rate and growth rate value, different filter treatments had insignificant different value in the FCR. The biological filter treatments had the FRC value of 1.2-1.3, while the control treatment had the FCR value of 2.4. These values were appropriate to the recommended FCR for catfish fry (SNI, 2000). A similar result was reported by Estim et al. (2019) in aquaponic culture with a combination of Nile tilapia Oreochromis niloticus, plant Phaseolus vulgaris, and Brassica rapa chinensis. This study described a more efficient system in plant growth and no impact was found in fish production, including the FCR value. Compared to Wicaksana (2015), the average value of FCR in this study was not significantly different as the average value of FCR on the African catfish fry maintained in aquaponic system was 1.15. According to Danahar et al. 2013 and Ardita et al. 2015, the lower FCR value produced, the higher feed efficiency value obtained to the fish. Water plant is a good biological filter due to capable of maintaining good water quality in the culture system (Zahidah et al., 2017; Abbey, 2019). Good water quality will support the fish growth and development, including feed efficiency improvement to support the growth. The use of Lemna minor and Wolffia arrhizal as biological filters could also decrease the FCR value of carp from 2.33 to 1.68 in a recirculation aquaculture system (RAS) (Velichkova \& Sirakov, 2013).

Based on Figure 6, the dissolved oxygen concentration during the maintenance period was more than $5 \mathrm{mg} / \mathrm{L}$, while the dissolved oxygen requirement of catfish fry based on SNI
6484.4:2014 should be at least $3 \mathrm{mg} / \mathrm{L}$. This indicates that all treatments provide optimal dissolved oxygen conditions for catfish. The catfish performance is strongly influenced by the water quality in aquaculture system, one of the most crucial components is the dissolved oxygen availability (Islami et al., 2017). Likewise, Putra et al. (2020) mentioned that increased dissolved oxygen through fine bubbles (FBs) technology greatly supports the growth of striped catfish (Pangasianodon hypopthalmus) in aquaponic system. The results of this study indicate that the use of various filters has an effect on the maintenance media water quality. The water quality of water in the maintenance tank must be maintained to produce the optimal fish growth (Andriani et al., 2018).

The water dissolved oxygen concentration in the recirculation system combined with bioball and water spinach had a higher average value than other treatments. The dissolved oxygen content was produced through a photosynthesis during the day from water spinach and atmosphere diffusion (Muhammad, 2016; Primashita, 2017). Decreased dissolved oxygen concentration was occurring in the fourth week and only found in the control treatment due to the excessive use of dissolved oxygen by fish, plants, and bacteria. The nitrifying bacteria require a lot of dissolved oxygen in the nitrification process. Therefore, there was a high possibility of competition between fish and bacteria to obtain the dissolved oxygen (Kordi \& Tancung, 2007).

The $\mathrm{pH}$ measured during the maintenance period as shown in Figure 7 was in the tolerance range for catfish growth, namely 7.59 8.48. This value followed the requirements stated in SNI (2014), as the $\mathrm{pH}$ value required for catfish should be 6.5-8.0. Although there were several values that slightly exceeded the optimal value, the deviation was very small, and it was believed that this deviation had no impact on the fish growth. This indicates that the use of various filters has no effect on the $\mathrm{pH}$ value of the cultured water.

Water temperature has a direct influence on fish, including influencing the growth and feed conversion ratio. Each fish species has a minimum and a maximum tolerance limit; therefore, the optimum temperature is required to ensure optimal growth and reproductive success. Based on SNI (2014), the optimal temperature for catfish growth should be $25^{\circ} \mathrm{C}-30^{\circ} \mathrm{C}$, while during the maintenance period in this study, the maintenance medium temperature was $20.10-21.87^{\circ} \mathrm{C}$. 
This condition indicates the unoptimal temperature for catfish growth, but this low temperature could still be tolerated by the catfish as Sing et al. (2013) stated that the tolerance limit for catfish was at $10^{\circ} \mathrm{C}-30^{\circ} \mathrm{C}$. Catfish response on low temperature was closely related to the physiological adaptation capability in catfish on temperature, as not an influenced from the filter treatments in the cultural process.

Ammonia concentration in the B (plant) and C (bioball and plant) treatments was higher than the A (bioball) and control (sponge) treatments. This was thought due to the increased feed requirement along with the increased catfish fry growth and limited absorption of nutrients by water spinach, causing the fry excretion waste increased. Muarif and Rosmawati (2011) explained that ammonia increased due to the increased metabolic wastes and feed remaining along with the maintenance period length. According to Effendi (2003); Primashita et al. (2017), increased feed requirement of fish can cause increased metabolite waste, which then occurs a feces accumulation. According to Zahidah et al. (2018), the capability of water spinach in absorbing nutrients can decrease along with the increased ammonia content. Therefore, the ammonia measurement result was increased. Zidni (2019a) also supported by the study results, which showed that the lowest ammonia value in the use of various plant types as filters was obtained from the water spinach treatmen at as biofilter, namely at $0.01 \mathrm{mg} / \mathrm{L}$.

Increased ammonia concentration which was quite high in the B treatment occurred as the water spinach roots often clogged the water outlet. This blockage caused fish metabolite waste and feed remaining to accumulate in the fish maintenance tanks and plant maintenance media. Catfish, based on SNI (2014) requires an ammonia concentration of should not be more than $0.01 \mathrm{mg} / \mathrm{L}$. Meanwhile, Wahyuningsih et al. (2015) stated that freshwater fish can tolerate ammonia concentrations to $0.15 \mathrm{mg} / \mathrm{L}$. Based on Figure 9, the measured ammonia concentration was among $0.0025-0.08 \mathrm{mg} / \mathrm{L}$. This indicates that although there was an increased ammonia content in the water spinach filter treatment closed to the tolerance limit, the ammonia content could still be tolerated by the catfish.

The ammonia content could affect the nitrate content in the culture media. Ammonia will decompose with the assistance of bacteria into nitrite and nitrate (Putra, 2011; Elbanna et al., 2012). The measurement result of ammonia concentration during the maintenance period was among $0.0025-0.125 \mathrm{mg} / \mathrm{L}$. This condition was still within the tolerance limit for fry catfish and tilapia growth. Based on Setijaningsih and Suryaningrum (2015), the safe concentration of nitrate value in fish culture was not more than 10-20 mg/L. Camargo et al. (2005) added that $10 \mathrm{mg} / \mathrm{L}$ nitrate concentration could affect on aquatic organisms, at least for a long exposure period. According to Utami et al. (2019), increased nitrate concentration is occurring due to a good recirculation system. This implicates on the balanced proliferation and activity of Nitrosomonas and Nitrobacter, which can oxidize ammonia to nitrite and nitrate with the assistance of Nitrobacter (Tanjung et al., 2019). According to Zidni et al. (2013), decreased nitrate concentration as a nutrient material in the maintenance media is occurred as nitrate is absorbed by the water spinach roots.

Phosphate is an essential element for higher plant level and algae, which can affect the plant productivity level (Barus et al., 2008; Rumanti et al., 2014). Goddek et al. (2016) stated that phosphate is a component that can be absorbed by plants to increase their biomass. Increased plant growth in an aquaponic system occurs due to increased phosphorus and nitrogen recycling process the efficiency (Wongkiew et al., 2017). Based on Ebeling et al. (2006), good phosphate concentration in fish culture was $0.2-1 \mathrm{mg} / \mathrm{L}$. Decreased phosphate concentration in the culture media in this study was thought due to water spinach absorption as a nutrient intake (Lestari et al., 2015; Hasan et al., 2017). A significant increase in phosphate concentration occurred in the third observation, which may occur due to related to decreased phosphate absorption by matured plants that were ready to be harvested (Wasonowati et al., 2013). In aquaponic culture system, water spinach plants can be harvested on the twelfth day of culture as the stem lengths reached 20-25 cm (Andriani et al., 2017).

\section{CONCLUSIONS}

The study results showed that there were significant differences in the survival rate and growth of catfish fry by using water spinach biofilter treatment with the survival rate of $100 \%$ and absolute growth rate of $98.32 \mathrm{~g}$. The water quality during the maintenance period was in the range to support the fish culture. 


\section{ACKNOWLEDGMENTS}

We would like to thank the Indonesian Ministry of Research, Technology, and Higher Education for the funding support through "Penelitian Dasar Unggulan Perguruan Tinggi (PDUPT)" research grant in 2017-2018.

\section{REFERENCES}

Abbey M, Anderson NO,Yue C, Schermann M, Phelps N, Venturelli P. 2019. Lettuce Lactuca sativa production in northern latitudinal aquaponic growing conditions. Hortscience 54: 1757-1761

Alam MNHZ, Othman NSIA, Samsudin SA, Johari A, Hassim MH and Kamaruddin MJ. 2020. Carbonized rice husk and cocopeat as alternative media bed for aquaponic system Sains Malaysiana 49: 483-492.

Alfia AR, Arini E, Elfitasari T. 2013. The effect of density differences on survival and growth of nile tilapia Oreochromis niloticus in recirculation system with bioball filter. Journal of Aquaculture Management and Technology 2: 86-93.

Andriani Y, Dhahiyat Y, Zahidah, Zidni I. 2017. The effect of stocking density ratio of fish on water plant productivity in aquaponics culture system. Nusantara Bioscience 9: 31-35.

Andriani Y, Dhahiyat Y, Zahidah, Subhan, Iskandar, Zidni I, Mawardiani T. 2018. Effect of water irrigation volume on Capsicum frutescens growth and plankton abundance in aquaponics system. IOP Conf. Series: Earth and Environmental Science 139 (2018) 01200.

Andriani Y, Zahidah, A.Yustiati, Junianto, Iskandar, E. Harditama. 2019. Productivity of various plants in aquaponics systems. Global Scientific Journal 7: 1222-1229.

Ardita N, Budiharjo A, Sari SLA. 2015. Pertumbuhan dan Rasio Konversi Pakan Ikan Nila Oreochromis niloticus dengan Penambahan Prebiotik. Bioteknologi 12: 1621

Barus TA, Sinaga SS, Tarigan R. 2008. Produktivitas primer fitoplankton dan hubungannya dengan faktor fisik-kimia air di perairan parapat, Danau Toba. Jurnal Biologi Sumatera 3: 11-16.

Boxman SE, Nystrom M, Ergas SJ, Main K L, and Trotz MA. 2018. Evaluation of water treatment capacity, nutrient cycling, and biomass production in a marine aquaponic system. Ecological Engineering 120: 299-310.

Camargo JA, Alonso A, and Salamanca A. 2005. Nitrate toxicity to aquatic animals: a review with new data for freshwater invertebrates. Chemosphere 58: 1255-1267.

Danaher JJ, R. Charlie S, James E. Rakocy and Donald S. Bailey.2013. Alternative solids removal for warm water recirculating raft aquaponic systems. Journal of the World Aquaculture Society 44: 374-383.

Danner RI, Utra M, Kesara AJ and Ragnheidur IT. 2019. Designing aquaponic production systems towards integration into greenhouse farming. Water 11: 1-21.

Darmayanti L, Yohanna L, dan Josua MTS. 2011. Pengaruh penambahan media pada sumur resapan dalam memperbaiki kualitas air limbah rumah tangga. Jurnal Sains dan Teknologi 10: 61-66

Dauhan RE, Efendi E, Suparmono. 2014. Efektifitas sistem aquaponik dalam mereduksi konsentrasi amonia pada sistem budidaya ikan. Jurnal Rekayasa dan Teknologi Budidaya Perairan 3: 297-312.

Direktorat Jenderal Perikanan Budidaya. 2013. Laporan Produksi Tahunan 2012/2013. 45 hlm.

Djarijah SA. 1995. Pakan Alami Ikan. Kanisius: Yogyakarta.

Gasperz, V. 1991. Metode Perancangan Percobaan. Bandung: CV Amrico.

Gichana Z, Paul M, Erick O, Silke D, Werner Z, David L, Peter A and Herwig. 2019. Growth and nutrient removal efficiency of sweet wormwood Artemisia annua in a recirculating aquaculture system for nile tilapia Oreochromis niloticus. Water 11: 1-14

Goddek S, Schmautz Z, Scott B, Delaide B, Keesman K, Wuertz S, Junge R. 2016. The effect of anaerobic and aerobic fish sludge supernatant on hydroponic lettuce. Agronomy 6: 37 .

Ebeling JM, Welsh CF, Rishel KL. 2006. Performance evaluation of an inclined belt filter using coagulation/flocculation aids for the removal of suspended solids and phosphorus from microscreen backwash effluent. Aquaculture Engineering 35: 61-77.

Effendi H, Bagus Amarullah UB, Darmawangsa GM, Karo karo RE. 2016. Fitoremediasi limbah budidaya ikan lele Clarias sp. dengan 
kangkung Ipomoea aquatica dan pakcoy Brassiica rapachinensis; dalam sistem resirkulasi. Jurnal Ecolab 9: 47-104.

Effendi H. 2003. Telaah Kualitas Air bagi Pengelolaan Sumber Daya dan Lingkungan Perairan Cetakan Kelima. Yogjakarta : Kanisius.

Effendie MI. 1979. Metode Biologi Perikanan. Yayasan Dewi Sri: Bogor.

Effendie MI. 1997. Biologi Perikanan. Yayasan Pustaka Nusatama: Yogyakarta.

Ekasari J, Setiawan R, Ritonga FR, Setiawati M, Suprayudi MA. 2019. Growth and health performance of African catfish Clarias gariepinus (Burchell 1822) juvenile fed with graded levels of biofloc meal. Aquaculture Research 2019: 1-10.

Elbanna Kh, El-Shahawy RM, Atalla KM. 2012. A New Simple Method for the Enumeration of Nitrifying Bacteria in Different Environment. Plant, Soil and Environment 58: 49-53.

Estim A, Saufie S, and Mustafa S. 2019. Water quality remediation using aquaponics subsystems as biological and mechanical filters in aquaculture. Journal of Water Process Engineering 30: 100566.

Fauzzia M, Rahmawati I, Dr. Widiasa NI, ST.MT. 2013. Penyisihan Amoniak dan Kekeruhan pada Sistem Resirkulasi Budidaya Kepiting dengan Teknologi Membran Biofilter. Jurnal Teknologi Kimia dan Industri 2: 155-161

Gaspersz V. 1991. Metode Perancangan Percobaan. Bandung: CV.ARMICO.

Hasan ZY, Dhahiyat, Andriani Y, Zidni I. 2017. Water quality improvement of Nile tilapia and catfish polyculture in aquaponics system. Nusantara Bioscience 9: 83-85.

Islami AN, Hasan Z, Anna Z. 2017. Effect of sphonization and aeration differences on water quality, growth, and survival of tilapia Oreochromis niloticus aquaculture stadia seed. Journal of Fisheries and Maritime Affairs 8: $73-82$.

Johnson GE, Buzby KM, Kenneth J. Semmens, Holaskova I, Waterland NL. 2017. Evaluation of lettuce between spring water, hydronponic, and flow-through aquaponic systems. International Journal of Vegetable Science 23: 456-470.

Kamauddin MJ, Ali Otman NSI, Abu Bakar MH, Johari A, and Hassim MH. 2019. Performance of water treatment techniques on cocopeat media filled grow bed aquaponics system. E3S
Web of Conferences 90: 1-10.

Kordi MG, Tancung AB. 2007. Pengelolaan Kualitas Air dalam Budidaya Perairan. Jakarta: Rineka Cipta..

Kushayadi AG, Saptono W, Diniarti N. 2018. Pengaruh media tanam akuaponik yang berbeda terhadap penurunan nitrat dan pospat pada pemeliharaan ikan mas (Cyprinus carpio). Jurnal Perikanan 8: 8-13.

Lennard W, and Simon Goddek. 2019. Aquaponics: The Basics. In book: Aquaponics Food Production Systems (pp.113-143). Wageningen University \& Research

Lestari NAA, Diantari R, Efendi E. Penurunan fosfat pada sistem resirkulasi dengan penambahan filter yang berbeda. 2015. E-Jurnal Rekayasa dan Teknologi Budidaya Perairan 3: 367-374.

Mahavadiya D, Sapra D, Rathod V, Sarman V. 2018. Effect a biotic and abiotic factors in feeding activity in teleost fish: A review. Journal of Entomology and Zoology Studies 6: 387-390.

Muarif, Rosmawati. 2011. kelangsungan hidup dan pertumbuhan benih ikan lele dumbo (Clarias Sp) pada sistem resirkulasi dengan kepadatan berbeda. Jurnal Pertanian 2: 36-47.

Muhammad M, Sayyid AER, Irma D. 2016. The growth and survival rates of tilapia juvenile Oreochromis niloticus in aquaponics systems with different plants species. Jurnal Ilmiah Mahasiswa Kelautan dan Perikanan Unsyiah 2: 183-193.

Naomi M, Hasan Z, Sumadi, Hamdani H, Andriani Y, and Subhan U. 2020. Growth of striped catfish fingerlings Pangasianodon hypophthalmus in aquaponic system with fine bubbles (FBs) application. Asian Journal of Fisheries and Aquatic Research 7: 1-9.

Nazlia S, dan Zulfiadi. 2018.The effect of different plants on aquaponics system on the survival rate and growth of catfish fingerling Clarias sp.. Acta Aquatica: Aquatic Sciences Journal 5: 14-18.

Ogunji J, Toor JRS, Shulz C, Kloas W. 2008. Growth performance, nutrient utilization of Nile tilapia Oreochromis niloticus fed housefly maggot meal (magmeal) diets. Turkish Journal of Fisheries and Aquatic Sciences 8: 141-147.

Patillo DA. 2017. An Overview of Aquaponic Systems: Aquaculture Components. NCRAC Technical Bulletin 20. http://lib.dr.iastate.edu/ ncrac_techbulletins/20. 
Pinheiro I, Carneiroa RFS, Vieiraa FN, Gonzagab LV, Fettb R, Costab ACO, Magallón-Barajasc FJ, Seiffert WQ. 2020. Aquaponic production of Sarcocornia ambigua and Pacific white shrimp inbiofloc system at different salinities Aquaculture 519: 1-9.

Putra DA, Hasan Z, Handaka AA, Hamdani H, and Subhan U. 2020. The potential effect of using fine bubbles on the growth rate of striped catfish Pangasianodon hypopthalmus fingerlings with different stocking densities in aquaponic systems. Asian Journal of Fisheries and Aquatic Research 7: 10-19.

Putra I, Setiyanto DD, Wahyuningrum D. 2011. Growth and survival nile tilapia Oreochromis niloticus on recirculation system. Journal of Fisheries and Marines 16: 56-63.

Primashita AH, Boedi Setya R, Prayogo. 2017. Effect addition of different probiotic in aquaponic systems towards the growth rate and survival rate of catfish Clarias sp.. Journal of Aquaculture Science 1: 1-9.

Rumanti M, Rudiyanti S, Suparjo MN. 2014. Hubungan Antara Kandungan Nitrat dan Fosfat dengan Kelimpahan Fitoplankton di Sungai Bremi Kabupaten Pekalongan. Diponegoro Journal of Maquares 3: 168-176

Samsundari S, Wirawan GA. 2013. Analisis penerapan biofilter dalam sistem resirkulasi terhadap mutu kualitas air budidaya ikan sidat Anguilla bicolor. Jurnal Gamma 8: 86-97.

Siswadi dan T Yuwono. 2015. Pengaruh macam media terhadap pertumbuhan dan hasil selada Lactuca sativa L. hidroponik. Jurnal Agronomik 9: 257-264

Setijaningsih L, Suryaningrum LH. 2015. Pemanfaatan limbah budidaya ikan lele Clarias batrachus untuk ikan nila Oreochromis niloticus dengan sistem resirkulasi. Jurnal Ilmu-ilmu Hayati LIPI. Berita Biologi 14: 287-293.

Singh SP, Sharma JG, Ahmad T, Chakrabarti R. 2013. Effect of water temperature on the physiological responses of Asian catfish Clarias batrachus (Linnaeus, 1758). Asian Fisheries Science 26: 26-38.

Sulasi, Hastuti S, Subandiyono. 2018. Pengaruh enzim papain dan probiotik pada pakan buatan terhadap pemanfaatan protein pakan dan pertumbuhan ikan mas Cyprinus carpio. Jurnal Sains Akuakultur Tropis 2: 1-10

SNI. 2000. Produksi benih ikan lele dumbo (Clarias gariepinus $x$ C. fuscus) kelas benih sebar. Badan Standarisasi Nasional. Jakarta. $10 \mathrm{hlm}$.

SNI. 2014 Ikan lele dumbo (Clarias sp.) Bagian 4 : Produksi benih. Badan Standarisasi Nasional. Jakarta. $10 \mathrm{hlm}$.

Stathopoulou P , Berillis P, Levizou E , Sakellariou-Makrantonaki M, Kormas AK , Angelaki A, Kapsis P, Vlahos N and Mente E. 2018. Basil and Nile tilapia production in a small scale aquaponic system. Journal of Fisheries Science 12: 1-3

Tanjung RRM, Zidni I, Iskandar, Junianto. 2019. Effect of difference filter media on recirculating aquaculture system (RAS) on tilapia Oreochromis niloticus production performance. World Scientific News 118: 194-208

Turnsek M, Joly A, Thorarinsdottir R, and Junge R. 2020. Challenges of commercial aquaponics in europe: beyond the hype. Water 12: 1-18

Utami TSB, Hasan Z, Syamsuddin ML, and Hamdani H. 2019. Fitoremediasi limbah budidaya ikan koi Cyprinus carpio dengan beberapa tanaman sayuran dalam sistem resirkulasi akuaponik. Jurnal Perikanan dan Kelautan 10: 81-88.

Velichkova K, Sirakov I, Georgiev G. 2013. Cultivation of Scenedesmus dimorphus strain for biofuel production. Agricultural Science and Technology 5: 181-185.

Wahyuningsih S, Effendi H, Wardiatno Y. 2015. Nitrogen removal of aquaculture wastewater in aquaponic recirculation system. AACL BIOFLUX 8: 491-499.

Wasonowati C, Suryawati S, Rahmawati A. 2013. Respon dua varietas tanaman selada Lactuca sativa L. terhadap macam nutrisi pada sistem hidroponik. Jurnal Agroekoteknologi (Agrovigor) 1: 50-72.

Wicaksana SN, Hastuti S, Arini E. 2015. Production performance of African catfish Clarias gariepinus maintained by biofilter aquaponics system and conventional. Journal of Aquaculture Management and Technology 4: 109-116.

Wongkiew S, Hu Z, Chandran K, Lee JW, Khanal SK. 2017. Nitrogen transformations in aquaponic systems: A review. Aquacultural Engineering 76: 9-19.

Yang T, Kim HK. 2019. Nutrient management regime affects water quality, crop growth, and 
nitrogen use efficiency of aquaponic systems. Scientia Horticulturae 256: 1-15.

Yep B and Youbin Zheng. 2019. Aquaponic trends and challenges: a review. Journal of Cleaner Production 228: 1586-1599.

Zahidah, Dhahiyat Y, Andriani Y, Zidni I. 2017. Water quality improvement of Nile tilapia and catfish polyculture in aquaponics system. Nusantara Bioscience 9: 83-85.

Zahidah, Andriani Y, Dhahiyat Y, Nurruhwati I, Sahidin A, Hamdani H, Victoria SM. 2018. Inorganic nitrogen absorption in the aquaponics farming of sangkuriang catfish Clarias gariepinus at uneven retention periods. Jurnal Akuakultur Indonesia 17: 130-136
Zidni I, Herawati T, Liviawaty E. 2013. Effect of density on growth sangkuriang catfish Clarias gariepinus in aquaphonic system. Jurnal Perikanan Kelautan 4: 315-324.

Zidni I, Iskandar, Rizal A, Andriani Y, Ramadan R. 2019a. Efektivitas sistem akuaponik dengan jenis tanaman yang berbeda terhadap kualitas air media budidaya ikan. Jurnal Perikanan dan Kelautan 9: 81-94.

Zidni I, Iskandar, Buwono ID, and Mahargyani BP. 2019b. Water quality in the cultivation of catfish Clarias gariepinus and Nile tilapia Oreochromis niloticus in the aquaponic biofloc system. Asian Journal of Fisheries and Aquatic Research 4: 1-6. 